Andrzej Pawlik, dr hab. prof. UJK Jan Kochanowski University in Kielce

Kielce, Poland ORCID: https://orcid.org/0000-0003-2319-6707

Pawel Dziekański, dr. Jan Kochanowski University in Kielce

Kielce, Poland ORCID: https://orcid.org/0000-0003-4065-0043

DOI: https://doi.org/10.30525/978-9934-26-036-0-5

\title{
APPLICATION OF THE TOPSIS METHOD TO ASSESS THE SPATIAL DIVERSITY OF THE ATTRACTIVENESS OF COMMUNES IN THE ŚWIĘTOKRZYSKIE VOIVODESHIP
}

Attractiveness is the ability to induce socio-economic activity by offering a combination of location benefits that can be achieved while running it. It is characterized by the characteristic features of the area in which the activity is developed. Attractiveness is a set of regional location advantages that affect the achievement of socio-economic goals, such as the development of costs of business activity, sales revenues, profitability and competitiveness, or allow to reduce the risk of failure in socio-economic activity. It is also related to the level of economic development. The areas offering the optimal combination of location factors are attractive as they allow on the reduction of capital expenditure and current operating costs, facilitating the maximization 
of profits and reducing the risk of business failure (Pawlik, Dziekański, 2020; Atrakcyjność inwestycyjna regionów 2016).

The main aim of the study is to analyze the differentiation in the attractiveness of communes in the Świętokrzyskie Voivodeship on the basis of a synthetic measure. Its construction was based on data from the Local Database of the Central Statistical Office (BDL GUS) for the years 2009-2018. The analyzes were carried out in the system of 102 communes of the Świętokrzyskie Voivodeship.

In the process of creating a synthetic feature, the following stages were distinguished: 1) selection of variables describing the tested objects; 2) assessment of the preferences of variables in relation to the phenomenon under consideration (their division into stimulants and destimulants) and standardization according to the method of zero unitarisation, 3) determination of a synthetic measure in accordance with the Technique for Order Preference by Similarity to an Ideal Solution (TOPSIS) method and based on distances in real space by Euclidean metric for individual objects, 4) division of the studied area into 4 quartile groups and analysis of correlation measures (Kukuła, 2000; Malina, 2004; Behzadian et al. 2012; Dziekański, Pawlik, 2019; Dziekański et al. 2020, Dziekański, Prus, 2020).

\section{Characteristics of the Świętokrzyskie Voivodeship}

The Świętokrzyskie Voivodeship is divided into the industrial north and the agricultural south. It focuses on traditional industries related to the production and processing of metals, mining and processing of mineral resources and the production of food products. The analysis of the development of the Swiętokrzyskie Voivodeship in territorial terms indicates that the spread of economic effects takes place only in the immediate vicinity of Kielce and subregional centers. Hence, an extremely important role in improving the quality of life of the inhabitants of peripheral areas must be played by local centers, such as: Sandomierz, Busko Zdrój, Włoszczowa, Pińczów, Ostrowiec Św., Starachowice, Skarżysko-Kamienna.

Despite its convenient location, among the largest Polish centers of economic activity and in the vicinity of the main transport corridors, the voivodeship is characterized by relatively low external transport 
accessibility and a poor degree of communication with the most important transport lanes in its vicinity. The activities of the companies are focused on: construction and mining and processing industries based on mineral resources in the northern part of the voivodeship. The southern and eastern part of the Świętokrzyskie Voivodeship is an area where agricultural and forestry activities are concentrated. There are also branches of industry that were mainly shaped during the creation of the Central Industrial District. This part of the area is also affected by the process of gradual depopulation associated with the migration of inhabitants inside and outside the region.

The demographic situation in the Świętokrzyskie Voivodeship is one of the most unfavorable in the country and indicates a significant and growing barrier to socio-economic development. The voivodship has more advanced processes of depopulation, deurbanization and aging of the population, the particularly unfavorable impact of which will be felt earlier than in other areas of Poland (Development Strategy of the Świętokrzyskie Voivodeship until 2030). The region's attractiveness is influenced by, among others: a well-developed network of training and lifelong learning institutions, a welldeveloped scientific base, mainly in the field of technical sciences, and a relatively well-developed network of higher business education.

\section{Spatial differentiation of the attractiveness of communes in Świętokrzyskie voivodships}

Figure 1 presents the classification of rural communes in eastern Poland in terms of their financial situation (the best units are marked in black, the lighter the color, the weaker units). The classification of communes was carried out on the basis of quartiles, which were the threshold values for subsequent groups.

The TOPSIS synthetic measure of attractiveness varied in 2018 from 0.2 in the municipalities: (Bejsce (2), Lipnik (2), Obrazów (2), Wilczyce (2)) to 0.44 in Kielce (1), and in 2009 from 0.18 Wilczyce (2) to 0.41 Kielce. The value of the range was 0.23 in 2009 , and 0.22 in 2018, which indicates a slight decrease in the differentiation of units in terms of financial situation. The best situation in terms 
of attractiveness was characterized by communes with high values of variables, e.g. economic potential, development, infrastructure, demographics and the labor market, and financial situation. In 2018, the highest attractiveness index was recorded in the following municipalities: Kielce (1), Morawica (3), Sandomierz (1), SitkówkaNowiny (2), Krasocin (2), Busko-Zdrój (3), Daleszyce (3), Ostrowiec Świętokrzyski (1). Their attractiveness was determined by the developmental, economic, financial and infrastructural potential.
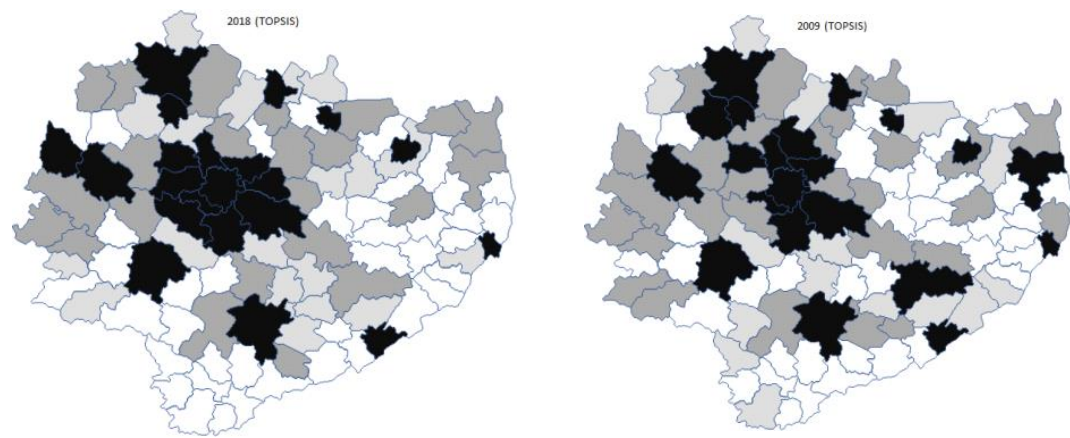

Figure 1. Spatial differentiation of the synthetic measure of attractiveness of communes in the Świętokrzyskie Voivodeship in 2009 and 2018

The attractiveness classes were determined on the basis of quartiles $2,3,4$. The black color means the best units, the lighter the color, the weaker the units.

Source: own study based on data from the Central Statistical Office of Poland and RIO in Kielce

Communes play a fundamental role in the economic and social system of the country, acting as centers of economic and cultural activity. The communes of the Świętokrzyskie Voivodeship are spatially polarized in terms of finances, infrastructure and economic potential, which shape the processes taking place in them. Their spatial diversity is influenced by: the level of development, the nature of the economy, e.g. agriculture, industry, tourism, and the location in relation to a strong urban unit. 
The communes located in the immediate vicinity of the city of Kielce are more attractive compared to the others. Location in the vicinity of the largest center - the capital of the voivodeship multiplies the activity of areas towards the development of new economic initiatives. The following units dominate in this respect: Morawica (3), Sitkówka-Nowiny (2). The least attractive in the voivodeship are, among others peripherally located, agricultural, with poorly developed service functions and infrastructure neglected communes (2), including: Baćkowice, Klimontów, Iwaniska.

The construction of the synthetic measure made it possible to measure the multidimensional phenomenon, as well as the linear ordering of the studied units. It can be a helpful tool for the regional self-government authorities in assessing the accuracy of decisions made in the past and the effectiveness of the regional management instruments used in the future. It made it possible to identify weaker and better areas of an individual's activity, and to include the individual in an appropriate group. The value of the measure depends on the number and type of variables adopted for the study.

\section{References:}

1. Atrakcyjność inwestycyjna regionów 2016 (2016) Województwo świętokrzyskie, Raport przygotowany na zlecenie Polskiej Agencji Informacji i Inwestycji Zagranicznych S.A. w Instytucie Przedsiębiorstwa Szkoły Głównej Handlowej w Warszawie Warszawa.

2. Dziekański P., Pawlik A. (2019) Intraregional diversification of the level of the financial situation of the poviats of Eastern Poland in relation to the development potential. Baltic Journal of Economic Studies, vol. 5, no. 3.

3. Dziekański P., Pawlik A., Wrońska M., Karpińska U. (2020) Demographic potential as the basis for spatial differentiation of the financial situation communes of Eastern Poland in 2009-2018. European Research Studies Journal, vol. 23, no. spec. 2.

4. Dziekański P., Prus P. (2020) Financial diversity and the development process: Case study of rural communes of Eastern Poland in 2009-2018. Sustainability, vol. 12 , no. 16.

5. Kukuła K. (2000) Metoda unitaryzacji zerowanej. Warszawa: Wydawnictwo Naukowe PWN.

6. Malina A. (2004) Wielowymiarowa analiza przestrzennego zróżnicowania struktury gospodarki Polski według województw. Kraków: Wyd. AE, Kraków. 
7. Behzadian M., Khanmohammadi Otaghsara S., Yazdani M., Ignatius J. (2012) A state-of the-art survey of TOPSIS applications. Expert Systems with Applications, no. 39(17).

8. Pawlik A., Dziekański P. (2020) Atrakcyjność miast i gmin województwa świętokrzyskiego. Wyd. UJK, Kielce.

9. Strategia Rozwoju Województwa Świętokrzyskiego do roku 2030 (2020) Urząd Marszałkowski, Kielce. 